\title{
The Effect of Using the E-Module Assisted by the Kvisoft Flipbook Maker in Improving Student's Critical Thinking Skills During the Covid-19 Pandemic
}

\author{
Ardila Safitri ${ }^{1, *}$ Mika Dwi Permata ${ }^{1,}$ Insih Wilujeng ${ }^{2}$ \\ ${ }^{1}$ Master of Physics Education, Faculty of Mathematics and Natural Sciences, Universitas Negeri Yogyakarta, \\ Indonesia. \\ ${ }^{2}$ Department of Natural Sciences Education, Faculty of Mathematics and Natural Sciences, Universitas Negeri \\ Yogyakarta, Indonesia. \\ *Corresponding author. Email: ardilasafitri.2019@student.uny.ac.id
}

\begin{abstract}
This type of research is quasi-experimental considered with a quantitative approach. The reason for this considered was to see the effect of e-modules assisted by KFM in improving student's critical thinking skills. The subjects in this think about are understudy at SMAN 1 PAKEM course XI IPA 2 (modelling course) and lesson XI IPA 3 (implementation course). Subjects were decided by the purposive sampling method. Based on the comes of the research that has been done, it can be expressed that the utilize of e-modules assisted by the Kvisoft Flipbook Maker can make students critical thinking skills. The comparison of the comes about of the pre-test and post-tests in each lesson (modelling and implementation classes) is the same, namely the increase in student scores. These results prove that the KFM-assisted e-module is viably utilized to makes strides in student's critical thinking skills.
\end{abstract}

Keywords: E-module, Kvisoft flipbook maker, Critical thinking skills, COVID-19

\section{INTRODUCTION}

Right now, the world is being stunned by the flare-up of an illness caused by the coronavirus or what is known as the COVID-19 (Coronavirus Diseases-19). COVID-19 could be a modern sort of malady that has never been already recognized. Common signs and side effects of COVID-19 contamination consolidate intense respiratory issues such as fever, hacking, shortness of breath, causing passing. On January 30, 2020, WHO has assigned the COVID-19 case as an open wellbeing crisis that's alarming the world [1]. The COVID-19 pandemic could be a genuine issue that must be faced by the world, its effect is additionally felt by the world of education [2].

On March 24, 2020, the Serve of Instruction and Culture of the Republic of Indonesia issued Circular Number 4 of 2020 which contains instruction arrangements within the crisis period of the spread of
COVID-19, in this circular, it is clarified that the learning handle is carried out at domestic through online or separate learning. So that the learning system must be replaced with online learning so that the learning process continues [3]. Learning patterns must also change, teachers are required to provide learning materials via digital remote devices [4]. Online learning is becoming learning that involves elements of data innovation within the learning process.

The development of science and technology in the 21 st century has ended up a potent and exceptionally powerful within the field of instruction[5]. The 21stcentury education framework requires instructors to innovate in learning [6]. Not only teachers are required to innovate in learning, but 21 st-century instruction also requires students to have the ability to ace higher-level concepts [7]. Critical thinking skills are one of the aptitudes that understudies must have to be meet the challenges of 21 st-century education 
[8]. Critical thinking skills are the most objective the understudies must accomplish

In some countries, critical thinking skills have become the most center of learning at all levels of instruction [9]. Likewise, in Indonesia, critical thinking skills are the most center of the competencies that students must accomplish at the education level [10]. Critical thinking skills are an important way of thinking, which is an important element in learning [11]. Critical thinking skills are one of the cognitive skills needed in identifying, analyzing, evaluating arguments, finding and solving problems, formulating and presenting reasons for concluding [12]. Education of critical thinking skills must be given to students from the time they are small [13]. The critical thinking skills of students also affect the academic success and professionalism of students in the future [12]. Learning to think critically is an important goal that must be achieved in education [14]. Every student must have critical thinking skills to meet the challenges of 21st-century education oriented towards high-level abilities, one of which is critical thinking skills.

In fact, the critical thinking skills of students are still considered moo [15]. The critical thinking skills of students in solving a problem are still considered low with a percentage of $34 \%$ for classification, $46 \%$ for assessment, $26 \%$ for making conclusions, and $12 \%$ for problem-solving strategies [16]. The moo critical thinking skills of students are appeared by the trouble of communicating conclusions, this can be since students don't get the material being considered so that they are not sure within the answers specified and as it was reply based on fundamental information [17]. It can be concluded that students 'critical thinking skills are still considered moo, so the need for a learning process that is directed to progress student's critical thinking skills. particularly in learning physics, which requires critical thinking skills.

Learning physics as part of science education must be able to develop competencies in problemsolving and makes strides in critical thinking skills of understudies, to be able to assess the critical thinking skills of each student [14]. The reason for learning physics is to improve the capacity of students to think systematically, objectively, and creatively [18]. If students are allowed to utilize considering at a better level, then students will get used to distinguish between appearance and reality, truths and suppositions, as well as knowledge and beliefs. So that it raises the critical thinking skills of students to master physics in profundity [19]. Critical thinking skills are the main components that students must have to learn physics more deeply.

Solving problems faced in life using the scientific method is one of the roles in physics. The role of physics to solve problems faced, especially in considering the understanding, benefits, and effect of technological developments in life require high-level skills, one of which is critical thinking skills [20]. Physics is one of the branches of science that underlies the development of science and innovation. In studying physics, students are expected to have higher-order thinking skills, one of which is critical thinking skills [21]. Technology makes it easier to develop thinking skills from the most basic level to the level of critical thinking skills [22].

Making the learning process interesting and fun is not difficult because of the increasingly sophisticated developments in science and technology. An interesting and fun learning process can be created by utilizing technology, science, such as being used as teaching material to support the learning process [23]. Based on the shape, the teaching materials are grouped into prints, teaching materials, listening teaching materials, and listening teaching materials. Following the increasingly advanced times, the teaching materials used are not only in the form of textbooks but, can also be taken from the internet and other sources such as journals, articles, electronic books (e-books), and electronic modules (e-module). So that it makes it easier for students to access subject matter to be studied. Teaching materials play an important role within the learning preparation. Without educating materials, it'll be troublesome to get effectiveness in learning.

E-modules are used as technology-based educating materials that can be utilized within the learning preparation. The E-module is more effective to use than a print module. The e-module is more interactive, makes it easier to navigate, has various features for inserting images, video, and movement components, and is prepared with formative tests or tests, and is more practical to use and carry anywhere because e-modules can be used anywhere and anytime [24]. The learning process using e-modules makes students not depend on the teacher as the only source of information [25]. E-modules or electronicbased modules are useful as conveyors of information contained in the hard disk, compact disk (CD), APK, ex, or web format to help students learn independently [26]. An E-module is an amalgamation of print media and computers so that it can present information in a structured, attractive manner and has a high level of interactivity [27]. 
E-module-assisted software (software) to read it is very effective to use. One of the software that can be used is the Kvisoft Flipbook Maker (KFM) application. KFM is open-source software. This software is used to create a display of teaching materials into an advanced electronic teaching material within the frame of a flipbook [25]. This KFM application is designed to change the appearance of a PDF file into a turning page of a digital publication like a book so that the appearance of the file becomes more attractive [28]. KFM makes media display more shifting. Not as it were text, images, video, and audio can moreover be inserted in this media so that the learning prepare will be more curiously [29].

KFM makes the module display an electronic module in the form of a Flipbook that can be accessed offline. E-modules assisted by KFM can make students better understand and explore the material [30]. Also, the KFM assisted e-module received a positive value because the learning material learned by students became very easy to understand. Besides, the operation is very easy. Music and animation elements are considered to increase the motivation, interest, and learning activities of students [25]. So that the e-module assisted by the KFM application to read it is very effective to use because it can train student's critical thinking skills.

This paper discusses the advancement of student's critical thinking skills which can be solved through learning innovation. One form of innovation provided is the use of e-modules assisted by Kvisoft Flipbook Maker so that it can make strides in student's critical thinking skills on global warming material.

\section{RESEARCH METHOD}

This type of research is a quasi-experiment with a quantitative approach. The reason for this consideration was to decide the impact of using KFM assisted e-modules in making strides in student's critical thinking skills. The investigation strategy utilized was pre-experiment with a one-group pretestposttest research plan [30]. In general, the research plan utilized can be seen in Table 1 .

Table 1. One group pretest-posttest design

\begin{tabular}{|c|c|c|}
\hline Pre-test & Treatment & Post-test \\
\hline $\mathrm{O}_{1}$ & $\mathrm{X}$ & $\mathrm{O}_{2}$ \\
\hline
\end{tabular}

Column $\mathrm{O}_{1}$ in Table 1 is the pre-test question questionnaire, column $\mathrm{O}_{2}$ is the post-test question questionnaire and column $\mathrm{X}$ is the use of a KFM assisted e-module. The subjects in this ponder were students in class XI IPA 2 and XI IPA 3 at SMAN 1 PAKEM. Class XI IPA 2 is the modelling class and class XI IPA 3 is the implementation class. Subjects were decided by the purposive sampling method. Subjects in the study consisted of 31 students of class XI IPA 2 and 31 students of class XI IPA 3.

The variables in this study are divided into two forms, namely independent and subordinate factors. The autonomous variable in this ponder is the utilize of e-module assisted by KFM, whereas the subordinate variable is the critical thinking capacity of students. The test set is an instrument used in this consider to decide the thinking skills of students. This test was performed at the pre-test and post-test. The data in this consider are information on student's critical thinking skills obtained from the learning handle. Information investigation utilized quantitative and qualitative analysis techniques. The instrument data for assessing critical thinking skills on the pretest and post-test produced by the modelling and implementation class were analyzed using descriptive statistics and the sign test using the SPSS application.

\section{RESULT AND DISCUSSION}

The results of measuring student's critical thinking skills were gotten from the pretest and posttest scores. Measurement information was analyzed utilizing descriptive statistics using the SPSS application. The following is the data on the results about measuring the critical thinking skills of students in the modeling class, namely class XI IPA 2 , which can be seen in Table 2 .

Table 2. Descriptive statistic of student's critical thinking skills in modelling class

\begin{tabular}{|l|l|l|l|}
\hline & Pre-test & Post-test & $\begin{array}{l}\text { Valid N } \\
\text { (listwise) }\end{array}$ \\
\hline $\mathrm{N}$ & 31 & 31 & 31 \\
\hline Min & 56 & 64 & \\
\hline Max & 78 & 98 & \\
\hline Mean & 62.21 & 83.62 & \\
\hline $\begin{array}{l}\text { Std. } \\
\text { deviation }\end{array}$ & 6.69 & 8.63 & \\
\hline
\end{tabular}

The average pre-test score in the modelling class was 62.21 , whereas the average post-test score in the modelling class was 83.6. These data indicate that there are contrasts in critical thinking skills of students sometime recently and after learning is carried out with the treatment given. The results appeared that there was an increment in critical 
thinking skills in the modelling class before and after learning using KFM-assisted e-modules. The data is then analyzed using the sign test to get more convincing results. The results of the sign test output can be seen in Table 4. Whereas the number of students who have expanded can be seen in Table 3 underneath.

Table 3. Frequency of critical thinking skills in modeling class

\begin{tabular}{|l|l|c|}
\hline \multirow{3}{*}{$\begin{array}{l}\text { Posttest- } \\
\text { Pretest }\end{array}$} & $\begin{array}{l}\text { Negative Differences (Post- } \\
\text { test<Pre-test) }\end{array}$ & 0 \\
\cline { 2 - 3 } & $\begin{array}{l}\text { Positive Differences (Post- } \\
\text { test>Pre-test) }\end{array}$ & 31 \\
\cline { 2 - 3 } & Ties & 0 \\
\cline { 2 - 3 } & Total & 31 \\
\hline
\end{tabular}

Table 3 shows that the students' posttest scores were higher than the student's pretest scores. This means that the value of students has increased. Thus, it can be concluded that the thinking skills of students have expanded after implementing learning using KFM assisted e-modules. The results of statistical tests from these data can be seen in Table 4 .

Table 4. Statistical result sign test for students critical thinking skills in modelling class

\begin{tabular}{|l|l|}
\hline & Posttest-Pretest \\
\hline$Z$ & -5.659 \\
\hline Asymp. Sig. (2-tailed) & 0.000 \\
\hline
\end{tabular}

Based on statistical tests using the Sign Test, the $\alpha$ value is 0.00 . Because $\alpha<0.05, \mathrm{H}_{0}$ is rejected. Thus, it can be concluded that there's an increment in the critical thinking skills of students after using the KFM assisted e-module in the modeling class. The study was at that point proceeded by carrying out learning within implementation class, to be specific course XI IPA 3 to get more convincing research data. The learning implementation is carried out by a physics subject teacher as a companion to students in the class. The taking after data on the results of measuring the critical thinking skills of students in the implementation class obtained through the pretest and posttest assessment instruments can be seen in Table 5.

Table 5. Descriptive statistic of students critical thinking skills in implementation class

\begin{tabular}{|l|l|l|l|}
\hline & Pre-test & Post-test & $\begin{array}{l}\text { Valid N } \\
\text { (listwise) }\end{array}$ \\
\hline & 31 & 31 & 31 \\
\hline
\end{tabular}

\begin{tabular}{|l|l|l|l|}
\hline & Pre-test & Post-test & $\begin{array}{l}\text { Valid N } \\
\text { (listwise) }\end{array}$ \\
\hline & 45 & 64 & \\
\hline & 78 & 98 & \\
\hline & 61.94 & 84.9 & \\
\hline & 7.456 & 2.047 & \\
\hline
\end{tabular}

The average pretest score in the implementation class is 61.94 , while the average posttest score in the implementation class is 84.90. These data indicate that there are contrasts in critical thinking skills of students sometime recently and after learning is carried out with the treatment given. The comes about appeared that there was an increment in critical thinking skills in the implementation class before and after learning using KFM assisted e-modules. The data is then analyzed using the sign test to get more convincing results. The comes about of the sign test output can be seen in Table 7 . While the number of students who have increased can be seen in Table 6 below.

Table 6. Frequency of critical thinking skills in implementation class

\begin{tabular}{|l|l|l|}
\hline \multirow{5}{*}{$\begin{array}{l}\text { Posttest- } \\
\text { Pretest }\end{array}$} & $\begin{array}{l}\text { Negative Differences } \\
\text { (Post-test < Pre-test) }\end{array}$ & 0 \\
\cline { 2 - 3 } & $\begin{array}{l}\text { Positive Differences } \\
\text { (Post-test }>\text { Pre-test) }\end{array}$ & 31 \\
\cline { 2 - 3 } & Ties & 0 \\
\cline { 2 - 3 } & Total & 31 \\
\hline
\end{tabular}

Based on the information in Table 6 , it can be seen that 31 students had posttest scores that were higher than the pretest scores. That is, all students experience an increase in value based on the comes about of the pretest-posttest that students have done. Thus, it can be concluded that the thinking skills of students have increased after implementing learning using KFM assisted e-modules. The results of statistical tests from these data provide in Table 7.

Table 7. Statistical result sign test for students critical thinking skills in implementation class

\begin{tabular}{|l|l|}
\hline & Posttest-Pretest \\
\hline$Z$ & -5.659 \\
\hline Asymp. Sig. (2-tailed) & 0.000 \\
\hline
\end{tabular}

The $\alpha$ value obtained from the statistical comes about of the Sign Test is 0.00 . Because $\alpha<0.05$, H0 is 
rejected. Thus, it can be concluded that there's an increment in the critical thinking skills of students after using the KFM assisted e-module in the implementation class. Research is running smoothly amid the Covid-19 pandemic. In the learning process, students are guided by teachers and researchers with the assistance of the WhatsApp (WA) application. Learning the steps are implemented through the WA application starting from preparatory exercises, center exercises, and closing exercises.

Preparatory exercises begin by checking the attendance of students through voice notes in the WA application. Students will mention names and words present as evidence that students are ready to take part in learning. Before continuing learning, students must ensure that the e-module can be opened on their respective PC or laptop devices. After everything is ready, the researcher and the teacher then led the students to read the instructional instructions and learning materials in the e-module provided. The advantage of using e-modules is that they are more practical to use and carry anywhere because they can be used anywhere and anytime [24]. Information on e-modules is presented in a structured, attractive manner and has a high level of interactivity because it is an amalgamation of print media and computers [27].

Learning in an online environment makes it easier for students to investigate data from different sources rapidly and effectively. This can be what energizes students to learn to be critical and selective in choosing existing information concerning the issues given. Technology will help develop all kinds of thinking skills from the most basic level to critical thinking skills [31]. The provided e-module has the same component content as a normal print module. This e-module contains a few components, counting cover, preface, introduction, table of substance, study instructions, learning materials, hone questions, outline, and reference index. The difference that this e-module has is that the concepts developed in the material are related to examples or phenomena that occur in everyday life and encourage students to practice critical thinking skills.

The appearance of the e-module which is quite attractive with the material associated with material that contains implementation in everyday life makes the concept easier to understand and to be well embedded. Making it easier for students in learning and progressing student's critical thinking skills. Students can recognize an issue, gather relevant information, have many alternative problems solving, be able to conclude, be able to express opinions and be able to evaluate arguments.

E-modules assisted by KFM can make students better understand and explore learning material [32]. Besides, the operation is very easy. Music and animation elements are one of the reasons that can increase the motivation, interest, and learning activities of students [27]. E-module with the KFM application can improve students 'critical thinking skills as seen from the students' pretest and posttest scores in the modeling class and the implementation class which has both increased.

\section{CONCLUSION}

The use of e-modules assisted by the Kvisoft Flipbook Maker can improve student's critical thinking skills. These results prove that the KFMassisted e-module is effectively utilized to moved forward student's critical thinking skills.

\section{REFERENCES}

[1] G. Zhou, S. Chen, Z. Chen, Back to The Spring of 2020: Facts and Hope of COVID-19 Outbreak, Frontiers of Medicine 14(2) (2020) 113-116. DOI: https://doi.org/10.1007/s11684$\underline{020-0758-9}$

[2] P.K. Sahu, Closure of Universities Due to Coronavirus Disease 2019 (COVID-19): Impact on Education and Mental Health of Students and Academic Staff, Cureus 12(4) (2020) 1-6. DOI: https://doi.org/10.7759/cureus.7541

[3] E.J. Sintema, Effect of COVID-19 on The Performance of Grade 12 Students : Implications for STEM Education, EURASIA Journal of Mathematics, Science and Technology Education 16 (7) (2020) 1-6. DOI: https://doi.org/10.29333/ejmste/7893

[4] United Nations, Policy Brief : Education during COVID-19 and beyond, United Nations, 2020.

[5] B. Setiawan, D.K. Innatesari, W.B. Setiawan, The Development of Local Wisdom-Based Natural Science Module to Improve Science Literation of Students, Jurnal Pendidikan IPA Indonesia 6(1) (2017) 49-54. DOI: https://doi.org/10.15294/jpii.v6i1.9595

[6] S.N.B. Jamal, N.H.B. Ibrahim, J.B. Surif, Concept Cartoon in Problem-Based Learning: A Systematic Literature Review Analysis, Journal of Technology and Science Education 9(1) 
(2019) 51-58. DOI: https://doi.org/10.3926/jotse.542

[7] A.E. Damayanti, H. Kuswanto, The use of android-assisted comics to enhance students , critical thinking skill the use of android-assisted comics to enhance students' critical thinking skill, in: Journal of Physics: Conference Series, vol. 1440, IOP Publishing, Bristol, 2020, pp. 18. DOI: $\quad$ https://doi.org/10.1088/1742$\underline{6596 / 1440 / 1 / 012039}$

[8] S.D.S. Pradana, Parno, S.K. Handayanto, Pengembangan Tes Kemampuan Berpikir Kritis pada Materi Optik Geometri untuk Mahasiswa Fisika, Jurnal Penelitian dan Evaluasi Pendidikan 21(1) (2017) 51-64. DOI: https://doi.org/10.21831/pep.v21i1.13139

[9] R. M. Schmaltz, E. Jansen, N. Witkowski Redefining Critical Thinking: Teaching Students to Think like Scientists, Frontiers in Psychology 8(1) (2017) 1-4. DOI: https://doi.org/10.3389/fpsyg.2017.00459

[10] Wahyudi, N.N.S.P. Verawati, S. Ayub, S. Prayogi, Conceptual Framework of InquiryCreative-Process Learning Model to Promote Critical Thinking Skills of Physics Prospective Teachers, Jurnal Pendidikan Fisika Indonesia 15(1) (2019) 5-13. DOI: https://doi.org/10.15294/jpfi.v15i1.10693

[11] Mundilarto, H. Ismoyo, Effect of ProblemBased Learning on Improvement Physics Achievement and Critical Thinking of Senior High School Student, Journal of Baltic Science Education 16(5) (2017) 761-779.

[12] Haida, The Effectiveness Using Inquiry-Based Natural Science Module With Authentic Assessment to Improve The Critical Thinking and Inquiry Skills of Junior High, Jurnal Pendidikan IPA Indonesia 5(2) (2019) 209-215. DOI: https://doi.org/10.15294/jpii.v5i2.7681

[13] E. Zamroni, Muslihati, B.B. Lasan, N. Hidayah, Blended learning based on problem based learning to improve critical thinking ability of prospective counselors, in: Journal of Physics: Conference Series, vol. 1539, IOP Publishing, Bristol, 2020, pp. 1-9. DOI: https://doi.org/10.1088/1742$\underline{6596 / 1539 / 1 / 012039}$

[14] L. Viennot, N. Decamp, Activation of a Critical Attitude in Prospective Teachers: From
Research Investigation to Guidelines for Teacher Education, Physical Review Physics Education Research 14 (2018) 1-19. DOI: https://doi.org/10.1103/PhysRevPhysEducRes.1 4.010133

[15] A. Malik, Vitriani, M.M. Chusni, Improving Student Critical Thinking Skills Through Student Facilitator and Explaining Model in Momentum and Impulse Topik, Jurnal Penelitian dan Pengembangan Pendidikan Fisika 4(2) (2018) 55-63. DOI: https://doi.org/10.21009/1.04202

[16] Z.S. Pamungkas, N.S. Aminah, F. Nurosyid, Analisis Kemampuan Berpikir Kritis Siswa dalam Menyelesaikan Soal Literasi Sains Berdasarkan Tingkat Kemampuan Metakognisi, Center For Science Education 10(2) (2018) 254264.

DOI: https://doi.org/10.15408/es.v10i2.7932

[17] D.T. Tiruneh, M.D. Cock, A.G. Weldeslassie, J. Elen, R. Janssen, Measuring Critical Thinking in Physics: Development and Validation of a Critical Thinking Test in Electricity and Magnetism, International Journal of Science Mathematics Education 15(4) (2017) 663-682. DOI: https://doi.org/10.1007/s10763-016-9723$\underline{0}$

[18] R.S. Damayanti, A. Suyatna, Warsono, U. Rosidin, Development of authentic assessment instruments for critical thinking skills in global warming with a scientific approach, in: International Journal of Science and Applied Science Conference Series, vol. 2, Universitas Sebelas Maret, Surakarta, 2017, pp. 289-299. DOI:

https://doi.org/10.20961/ijsascs.v2i1.16730

[19] I.D. Kurniawati, Wartoni, M. Diantoro, The Effect of Peer Instruction Integrated Guided Inquiry Learning on Concepts Acquisition and Critical Thinking of Students, Jurnal Pendidikan Fisika Indonesia 10(1) (2014) 36-46. DOI: https://doi.org/10.15294/jpfi.v10i1.3049

[20] A. Malik, Y. Novita, A.Y. Nuryantini, Enhancing, Enhancing Critical Thinking Skills of Students Related to Temperature and Heat Topics through Problem Solving-Laboratory Model, Jurnal Penelitian dan Pengembangan Pendidikan Fisika 5(1) (2019) 9-20. DOI: https://doi.org/10.21009/1.05102 
[21] L. Herayanti, S. Gummah, B.A. Sukroyanti, Gunawan, M. Makhrus, Pengembangan Perangkat Pembelajaran Berbasis Masalah Meggunakan Media Moodle untuk Meningkatkan Keterampilan Berpikir Kritis Mahasiswa Pada Materi Gelombang, Jurnal Pendidikan Fisika dan Teknologi 4(2) (2018). 158-167.

DOI: https://doi.org/10.29303/jpft.v4i2.803

[22] D. Arini, R. Kustjono, The Development of Interactive Electronic Book (Budin) Using Flip PDF Professional to Train Higher Order Thinking Skills, Jurnal Inovasi Pendidikan Fisika 6(3) (2017) 312-318.

[23] R. Ardiansyah, A.D. Corebima, F. Rohman, Analisis kebutuhan pengembangan bahan ajar perubahan materi genetika pada matakuliah generika di Universitas Negeri Malang, in: Seminar Nasional Pendidikan dan Saintek, Universitas Muhammadiyah Surakarta, Surakarta, 2016, pp. 749-752.

[24] Apsari, A. Nindy, K.R. Kustijono, Development of E-book Using Kvisoft Flipbook Maker to Train Science Process Skills for Senior High School Students in Curriculum 2013, Jurnal Inovasi Pendidikan Fisika 6(3) (2017) 285-291.

[25] D. Sugianto, A.G. Abdullah, S. Elvyanti, Y. Muladi, Modul Virtual: Multimedia Flipbook Dasar Teknik Digital, Invotec 9(2) (2013) 101116.

DOI:

https://doi.org/10.17509/invotec.v9i2.4860

[26] I.W.B. Permana, I.M.A. Wirawan, I.G.P. Sindu, Learning pada Mata Pelajaran Pemrograman Berorientasi Objek Kelas XI RPL di SMK Negeri 2 Tabanan, Jurnal Nasional Pendidikan Teknik Informatika 6(2) (2017) 140-154. DOI: https://doi.org/10.23887/janapati.v6i2.11083

[27] D.U. Mulyadi, S. Wahyuni, R.D. Handayani, Pengembangan Media Flash Flipbook untuk Meningkatkan Keterampilan Berfikir Kreatif Siswa dalam Pembelajaran IPA di SMP, Jurnal Pembelajaran Fisika 4(4) (2016) 296-301.

[28] N.N. Mulyaningsih, D.L. Saraswati, Penerapan Media Pembelajaran Digital Book dengan Kvisoft Flipbook Maker, Jurnal Pendidikan Fisika Universitas Muhammadiyah Metro 5(1) (2013) 25-32.

DOI:
[29] H. Nufus, Susilawati, R. Linda, Implementation of E-Module Stoiciometry Based on Kvisoft Flipbook Maker for Increasing Understanding Study Learning Concepts of Class X Senior High School Hayati, Journal of Educational Sciences 4(2) (2020) 261-272. DOI: https://doi.org/10.31258/jes.4.2.p.261-272

[30] E. DePoy, L.N. Gitlin, Introduction to research Understanding and Applying Multiple Strategies, Mosby, 2013.

[31] I. M Suarsana, G.A. Mahayukti, Pengembangan E-Modul Berorientasi Pemecahan Masalah untuk Meningkatkan Keterampilan Berpikir Kritis Mahasiswa, Jurnal Pendidikan Indonesia 2(2) (2013) 264-275. DOI: https://doi.org10.23887/janapati.v2i3.9800 https://doi.org/10.24127/jpf.v5i1.741 